Marquette University

e-Publications@Marquette

4-1-2013

\title{
Charitable Ratings and Financial Reporting Quality: Evidence from the Human Service Sector
}

Qianhua Ling

Marquette University, qianhua.ling@marquette.edu

Daniel G. Neely

University of Wisconsin - Milwaukee

Published version. Journal of Public Budgeting, Accounting \& Financial Management, Vol. 25, No. 1 (Spring 2013): 69-90. DOI. (C) 2013 PrAcademics Press. Used with permission. 


\title{
CHARITABLE RATINGS AND FINANCIAL REPORTING QUALITY: EVIDENCE FROM THE HUMAN SERVICE SECTOR
}

\author{
Qianhua Ling and Danjel Gordon Neely*
}

\begin{abstract}
Prior research has shown that many donors utilize charity ratings for decisions and they give more to higher rated charities. Because ratings are partly or completely based on financial information, the financial reporting quality of highly rated charities is more critical to donors than that of the poorly rated ones. In this study, we examine whether the financial reporting quality of charities systematically varies with charitable ratings. Examining a sample of human service charities, we find that highly rated organizations are more likely to underreport fundraising expenses and overstate program ratios. Highly rated organizations appear to be exercising accounting discretion to achieve this desirable outcome. Collectively, our findings suggest that stakeholders should be cautious when they use the rating information.
\end{abstract}

\section{INTRODUCTION}

The number of nonprofit charitable organizations exempt from income tax has increased substantially in recent times. The information returns filed by these organizations rose from 207,272 in 1998 to 315,184 in 2008.1 In this environment, nonprofits face an increasingly competitive market for charitable contributions. Similarly, donors have an increasingly difficult task in selecting appropriate nonprofit recipients. As the number of choices goes up, donors increase their demand for financial information (Gordon \&

* Qianhua (Q.) Ling, Ph.D., is an Assistant Professor of Accounting at Marquette University. Her research interests are in financial reporting, governance, information intermediany, and especially in the governmental and nonprofit accounting area. Daniel Gordon Neely, Ph.D., CPA, is an Assistant Professor of Accounting at the University of Wisconsin-Milwaukee. His research interests are in governmental and nonprofit accounting. 
Khumawala, 1999). They are also more likely to rely on charity rating information for their decisions. Prior studies find that charitable ratings affect public contributions. Donors give more to highly rated organizations (Tinkelman, 1998; Sloan, 2009; Gordon et al., 2009). Because ratings are partly or completely based on financial information, the financial reporting quality of highly rated charities is more critical to donors than that of the poorly rated charities. In this study, we examine whether the financial reporting quality of nonprofits systematically varies with charity ratings.

The Taxpayer Bill of Rights 2 requires nonprofits in the U.S. to provide their financial information to the public via Internal Revenue Service (IRS) Form 990, Return of Organization Exempt from Income Tax. Nonprofits are required to file Form 990 annually and they provide a large amount of information on the Form. Rating agencies facilitate the processing of the information which intends to help stakeholders make informed decisions. Ratings provided by these information intermediaries generate at least three advantages. First, ratings greatly reduce the information processing cost for stakeholders by providing concise ratings. For example, The American Institute of Philanthropy (AIP) gives top performers a letter grade "A," followed by "B," "C," and "D." it assigns an " $F$ " to organizations with the least satisfactory performance. The Better Business Bureau's Wise Giving Alliance (BBB) has only two categories for the nonprofits. A nonprofit organization either "meets" or "does not meet" the BBB standards. The Charity Navigator summarizes its evaluation using a number of stars, zero, one, two, three, or four stars. The zero-star nonprofits are the least favorable and the four-star nonprofits are the most desirable.

Second, these rating systems promote sustainable practice. Judging charities based solely on the percentage of expenditures on charitable purposes and fundraising is not theoretically sound (Bhattacharya \& Tinkelman, 2009). Rating systems go beyond these two measures and try to neutralize this issue. For example, the BBB standards cover not only financial performance but also governance, oversight and measuring effectiveness. Charity Navigator analyzes charity performance in seven areas. ${ }^{2}$

Finally, the ratings incorporate the institutional knowledge of the rating agencies. For evaluation purpose, the BBB requires organizations to submit their budgets which allow the agency to 
analyze this privately available information (bbb.org). Charity Navigator varies its scoring criteria by sector (charitynavigator.org). For example, food banks operate with fewer administration activities than other charities. The cut-off point of the administrative expense ratio is much lower for these organizations to score a high rating.

Prior studies find a strong association between ratings and donations (Tinkelman, 1998; Sloan, 2009; Gordon et al., 2009). Tinkelman (1998) finds that non-individual donors respond negatively to unfavorable ratings, while Sloan (2009) reports that donors react to positive ratings only. Gordon et al. (2009) document a positive association between rating change and the change in contribution. These ratings rely heavily on financial information for assessment. For example, Charity Navigator, BBB, and AIP all evaluate an organization's program ratio. Because financial information can be misreported (e.g., Krishnan et al., 2006; Jones \& Roberts, 2006), it is important to examine whether highly rated charities are more likely to misreport their financial information.

In this study, we examine a hand-collected sample of human service organizations rated by Charity Navigator. Charity Navigator covers more charities than any other rating agencies. Its ratings range from zero to four stars with four-stars indicating top performance. A list of four-star charities is prominently displayed on the rating agency's website. The link to the list is posted on the top part of every webpage. Our analyses show that highly rated organizations are more likely to underreport fundraising expenses and overstate program ratios. We also find that these highly rated organizations tend not to engage in obvious misreporting practices such as zero fundraising expenses, zero executive compensation, or using joint costs to inflate program expenses. It appears that it is the generous allocation of expenses to the program category that contributes to the low fundraising expenses and high program ratios.

Our study contributes to the rating literature in two distinct ways. First, while prior studies examine the impact of ratings on donor decisions (Tinkelman, 1998; Sloan, 2009; Gordon et al., 2009), our study is the first to show rated nonprofits likely consider the rating implication in utilizing their financial reporting discretion. Our findings indicate that highly rated organizations present a higher degree of underreported fundraising expense and overstated program ratios. Second, we add to the literature by demonstrating that inflating 
program ratios may not be done in an extreme way such as reporting zero fundraising expense; rather, it may be done in a subtle way. For example, Keating et al. (2008) find that nonprofits may report smaller amounts of telemarketing expenses as fundraising expense than the amounts actually incurred. We provide some evidence that inflated program ratios may be because of the generous allocations of employee wages and benefits, and joint costs to the program expense category.

Collectively, our findings suggest that stakeholders should exercise judgment when they use the rating information. Stakeholders should not base their decisions solely on the ratings because nonprofits may use discretion in assigning expenses to different categories to show better performance. The findings from this study should stir debate about whether rating agencies contribute to creating an efficient philanthropic market or are unintentionally driving improper use of discretion in financial reporting practice.

The remainder of this paper is organized as follows. We discuss related prior literature first and then present our hypothesis which links ratings and reporting quality. Following that we report the measures of financial quality, sample selection, and findings. We provide a conclusion section at the end of the paper.

\section{RELATED PRIOR RESEARCH}

Prior research suggests that donors care about how effectively and efficiently nonprofits use donations. It is a challenge to measure effectiveness because effectiveness is difficult to quantify and nonprofits provide only limited disclosures in this regard (Parsons, 2003). However, financial information can be used to calculate efficiency measures. Financial information is widely available since charities were required to provide their Form 990 s to the public in 1996 (Gordon et al., 1999). Research suggests that donors respond to summary financial measures. One widely used summary financial measure is the program ratio, the percentage of total expenses devoted to the mission of the charity. From the donors' perspective, the program ratio is the inverse of their "price" to "purchase" a dollar of service for the beneficiaries of charitable efforts. The higher the program ratio, the lower the donor purchase price. An early study by Weisbrod and Dominguez (1986) find a negative relation between 
total donations and donor purchase price. Later studies such as Tinkelman (1999) also find a significantly negative relation between total direct contributions and donor purchase price. Research studying the phenomena in the United Kingdom (Posnett \& Sandler, 1989), Canada (Callen, 1994), and Singapore (Wong et al., 1998) reports similar findings. These studies suggest that donors reward efficient charities.

Another summary financial measure is the portion of expense spent on the administrative function. Low spending on administration leaves more funds for communicating and fulfilling the mission of the nonprofit. Greenlee and Brown (1999) define the administrative ratio as the portion of the total expense spent on administrative and program activities. They find that the ratio is negatively associates with total contributions. Tinkelman and Mankaney (2007) point out that some prior studies may contain observations with unreliable administrative ratios. They therefore restrict their samples to nonprofits that spend more than $\$ 1,000$ on fundraising and administrative functions, have been established for four or more years, have received more than $\$ 100,000$ in donations in the prior year, and whose donation is at least ten percent of prior year total revenue. Their findings generally support a significant negative association between the accounting measures of administrative efficiency and donations.

Watchdog groups publish ratings, aimed at helping donors choose nonprofit organizations. Tinkelman (1998) examines whether donations are lower if a nonprofit violates the standards set by the National Charities Information Bureau (NCIB) or the Council of Better Business Bureaus (CBBB). He finds that non-individual donors respond negatively to a violation of standards established by these agencies. Sloan (2009) studies the effect of the rating from the Better Business Bureau's Wise Giving Alliance on the amount of public support, grants, and dues received by nonprofits. She finds that a pass rating by the Alliance has a significantly positive effect. Using more recent data, Gordon et al. (2009) investigate the relation between the change in the Charity Navigator rating and the change in contributions. They report that contributions change with the change in the rating. The ratings in Tinkelman (1998) and Sloan (2009) evaluate a nonprofit's financial performance and governance practice, whereas the ratings in Gordon et al. (2009) evaluate financial 
performance based on information reported on Form 990s. Overall, donors prefer nonprofits with higher ratings and support these organizations with their scarce resources.

The above studies provide evidence that stakeholders rely on financial information for decision making. This may provide nonprofits with incentives to manage financial reporting. In addition, Form 990s are generally not required to be audited (Yetman \& Yetman, 2012) and the probability that the Form will be audited by the IRS is low (GAO, 2002). Misreporting is therefore possible. Indeed, some studies indicate that misreporting exists and the primary purpose is to inflate the program expense ratio (e.g., Trussel, 2003; Wing et al., 2006; Krishnan et al., 2006; Jones \& Roberts, 2006; Tinkelman, 2009). For example, Krishnan et al. (2006) report that many nonprofits engage in fundraising activities but fail to report fundraising expense or report smaller than actual amounts. The possibility of this misreporting increases with the sensitivity of executive compensation and donation to program ratios. Unique to nomprofits, if an activity serves a public education purpose and a fundraising appeal simultaneously. nonprofits can allocate the cost of this activity (i.e., joint costs) among program expense, fundraising expense, and administrative expense. Jones and Roberts (2006) find that nonprofits use both the level of joint costs and the share of joint costs allocated to programs to avoid reporting changes in program ratios. Keating et al. (2008) document that some nonprofits inappropriately net telemarketing expenses against revenue or understate the amount that should be reported as fundraising expense; in doing so, nonprofits report lower fundraising ratios and thus higher program ratios. In a recent case study, Tinkelman (2009) details how the Avon Foundation managed their reporting to meet rating agency guidelines. Specifically, prior to 2003 the Avon Foundation reported all special event expenses associated with a major fundraising event as fundraising expenses. However, from 2003 to 2006, large amounts of event expenses were unreasonably assigned to programs. This change in reporting enabled the Avon Foundation to meet the 2003 BBB guidelines.

\section{RATING AND FINANCIAL REPORTING QUALITY}

We examine the human service charities rated by Charity Navigator. Charity Navigator was founded in 2001. It is the largest nonprofit rating agency in the U.S. Charity Navigator evaluates over 
5,000 charities. Its rating information is free to the public and the website enables easy comparison of ratings across charities and over time. Stakeholders appear to increasingly rely on Charity Navigator ratings as over five million visits to the website occurred in 2011 and four million in 2007 (charitynavigator.org; Gordon et al., 2009). Analyzing Charity Navigator ratings, Gordon et al. (2009) show that changes in ratings are positively associated with changes and levels of contributions. Together with other studies (Tinkelman, 1998; Sloan, 2009), Gordon et al. (2009) provide evidence that higher ratings mean more donations.

The primary purpose of human service charities is to provide direct support to people in need such as the disadvantaged, the elderly, and the disabled. Gordon and Khumawala (1999) suggest that donors who are not direct beneficiaries of the charitable work are more likely to seek financial information than those who are. Following this theory, since donors of human service organizations are generally not direct beneficiaries of the charitable services, they are more likely to do comparison shopping. As a consequence, human service organizations may have strong incentives to report high financial performance and thus higher ratings. If misreporting prevails, one would expect that highly rated charities are likely to have poor reporting quality.

Alternatively, highly rated charities may be truly high quality organizations. The non-distribution nature of nonprofits likely limits the extent of self-serving management activity (Hansmann, 1980; Fama \& Jensen, 1983). Further, managers in nonprofits self-select into the sector. They are more driven by altruism and less by financial gains. To these managers, providing charitable services is a top priority and they try to minimize perquisites and fundraising activities (Rose-Ackerman, 1987). Managers of nonprofits may also have high ethical standards. Yetman (2001) reports that charities do not allocate expenses from tax-exempt categories to taxable categories to reduce tax liabilities. All these factors contribute to high operational performance and the performance is faithfully represented by the financial measures used to rate the charities.

In summary, the performance hypothesis argues for a positive association whereas the misreporting hypothesis argues for a negative association between ratings and reporting quality. Absent theories regarding the relative strength of these arguments, we do 
not take an a priori stand on which is more likely to dominate. Instead, we consider the association between ratings and reporting quality an empirical issue. Accordingly, we state the hypothesis in null form: there is no systematic reporting quality difference across ratings.

\section{MEASURES OF FINANCIAL REPORTING QUALITY}

Prior research suggests that in the nonprofit world the objective of an organization is not to maximize profit but to maximize charitable output. Partly because the quality of the output is difficult to measure, the focus is placed on the reported charitable spending (Parsons, 2003; Trussel, 2003). As donors and watchdog groups all show special interest in this spending, nonprofits have incentives to inflate reported program expenses. This may be done by underreporting fundraising and/or administrative expenses and thus overstating program spending (e.g. Trussel, 2003; Krishnan et al., 2006; Jones \& Roberts, 2006; Keating et al., 2008; Tinkelman, 2009).

We adopt three proxies for reporting quality. Our first measure relates to fundraising expenses. Nonprofits engage in various kinds of activities to raise funds. Higher fundraising expenses may not necessarily lead to higher contributions, but higher contributions (public support, indirect public support, and government grants) are very likely to be the result of higher fundraising expenses. Based on the discussion of the theoretical link between donations and fundraising expenses by Steinberg (1986), Yetman and Yetman (2012) develop a fundraising expense expectation model. To test whether charities understate their fundraising expenses, we estimate this expectation model. The residuals from the model are used as an indicator of reporting quality. A negative residual indicates that an organization reports less fundraising expenses than the model predicts. The lower the value, the higher the amount underreported. The fundraising expectation model is specified as: ${ }^{3}$

Fundraising Expenses Ex-1 $_{1}=\beta_{0}+\beta_{1}$ Direct Public Supportit

$+\beta_{2}$ Indirect Public Support ${ }_{i t}+\beta_{3}$ Government Grants

$+y_{k}$ Year Indicators $_{i t}+\delta_{j}$ Group Indicators $_{i t}+\varepsilon_{i}$

Similarly, to test whether administrative expenses are underreported, we estimate an administrative expense model. In addition to the contributions variables, this model includes Total Expenses, Total Assets, and the square of Total Assets. This reflects 
the fact that large organizations incur higher administrative expenses than smaller organizations and that administrative expenses increase at a diminishing rate. Following Yetman and Yetman (2012), the model is specified as:

$$
\begin{aligned}
\text { Administrative Expenses }_{i t-1}=\beta_{0}+\beta_{1} \text { Direct Public Support } & \\
& +\beta_{2} \text { Indirect Public Support } \\
& +\beta_{4} \text { Total Expenses } \beta_{i t}+\beta_{5} \text { Total Assetsit }+\beta_{6} \text { Total } \\
& \text { Assets }{ }^{2} \text { it }+\gamma_{k} \text { Year Indicatorsit }+\delta_{j} \text { Group Indicators } i t+\varepsilon_{i} \\
& (2)
\end{aligned}
$$

The residuals of this model are another indicator of reporting quality. The lower the value, the higher the amount underreported. We use the administrative expense residuals as our second measure of reporting quality.

Unlike the two measures above that indirectly suggest whether an organization inflates its program expenses or not, our last measure directly examines the program ratio. Building on Baber et al. (2001), the expected program ratio is a function of the organization's size, its strategy, and fundraising spending. The program ratio will be higher for larger organizations, lower for organizations approaching small donations, and lower for organizations spending more on fundraising. Trussel (2003) posits that organizations with standardized residuals significantly greater than zero at the $10 \%$ level (one-tailed) are very likely to overstate the program ratio, thus, they are potential accounting manipulators. The program ratio expectation model is:

$$
\begin{gathered}
\text { Program Expense } \left./ \text { Total Expense }{ }_{i t}=\beta_{0}+\beta_{1} \text { Ln (Total Revenue }{ }_{i t}\right) \\
+\beta_{2} \text { (Professional Fundraising Expense } / \text { Total } \\
\text { Expense } \left.{ }_{i t}\right)+\beta_{3} \text { (Total Fundraising Expenseit / Total } \\
\text { Contributionsit) }+\delta_{j} \text { Group Indicators }_{i t}+\varepsilon_{i}
\end{gathered}
$$

The performance hypothesis predicts that the fundraising expense residuals and the administrative expense residuals would be higher (more positive) for the highly rated organizations, and that there would be fewer potential accounting manipulators in the highly rated groups. The opposite is expected by the misreporting hypothesis. The highly rated organizations would show lower (more negative) fundraising expense residuals and/or administrative expense residuals, and there would be more potential accounting manıpulators in the highly rated groups. 


\section{SAMPLE}

Our rating information for the human service organizations was coliected from Charity Navigator in 2008. We start with 2,680 charityyear observations. We lose 38 observations during the matching process with the Guidestar financial information. We exclude 10 more observations because of a change in the fiscal year. Our final sample includes 2,632 charity-year observations. This sample selection process is presented in Table 1.

TABLE 1

Sample Selection

\begin{tabular}{|l|c|}
\hline & $\mathrm{N}$ \\
\hline Charity Navigator ratings & 2,680 \\
\hline Less: no financial information in Guidestar & 38 \\
\hline Less: fiscal year change & 10 \\
\hline Final sample & 2,632 \\
\hline
\end{tabular}

FINDINGS

We first establish whether organizations are likely to report their numbers inaccurately by comparing the fundraising residual, administrative expense residual, and program ratio residual from the previously discussed models (1), (2), and (3). All three models have a high explanatory power, $80 \%, 97 \%$, and $65 \%$ respectively, with a mean residual of zero. Table 2 reports the descriptive statistics of these residuals and the percentage of potential accounting manipulators by rating group. The four-star group has negative means and medians for fundraising residuals and administrative residuals. The three-star group also has a negative mean and median for fundraising residuals. Its administrative residuals have a negative median, but a positive mean. The means of fundraising and administrative residuals are positive for lower-rated groups. The program ratio residuals are greater for the highly-rated groups than the lower-rated groups. The percentage of possible accounting manipulators decreases with the ratings. 
TABLE 2

Descriptive Statistics for Residuals of Expectation Models and Potential Accounting Manipulators

\begin{tabular}{|l|l|c|c|c|c|c|}
\hline Variable & & $4-S t a r$ & $3-S t a r$ & $2-S t a r$ & 1-Star & O-Star \\
\hline \multirow{2}{*}{ FundResid } & Mean & -287 & -23 & 110 & 317 & 1,643 \\
\cline { 2 - 7 } & Median & -108 & -55 & 30 & 105 & 1,080 \\
\hline AdminResid & Mean & -51 & 7 & 13 & 138 & -196 \\
\cline { 2 - 7 } & Median & -95 & -80 & -85 & -36 & -233 \\
\hline ProgRatioResid & Mean & 0.02 & 0.00 & -0.01 & -0.03 & -0.08 \\
\cline { 2 - 7 } & Median & 0.02 & 0.01 & 0.00 & -0.03 & -0.04 \\
\hline ManageProgRatio & Mean & 0.51 & 0.42 & 0.38 & 0.23 & 0.13 \\
\hline Sample Size & & 748 & 945 & 632 & 252 & 55 \\
\hline
\end{tabular}

Note: This table represents descriptive statistics for the sample based on Charity Navigator Ratings. FundResid $=$ The residual (in $\$ 000$ ) from the fundraising expense expectation model (1); AdminResid $=$ The residual (in $\$ 000$ ) from the administrative expense expectation model (2); ProgRatioResid = The standardized residual from the program expense expectation model (3); ManageProgRatio $=1$ if the standardized ProgRatioResid is positive and statistically greater than zero at the $99 \%$ confidence level.

Table 3 presents statistical tests of differences between the mean residuals across rating groups. The statistical tests support the pattern we observe from Table 2 that highly rated organizations are more likely to understate fundraising expenses and overstate program expenses, resulting in higher program expense ratio residuals for highly rated nonprofits. Specifically, four- and three-star organizations understate their fundraising expenses relative to zero-, one-, or two-star organizations. The differences in administrative expenses are not statistically significant in many cases, and do not provide conclusive evidence of over- or under-stating. Because of high program ratio residuals, there are more potential accounting manipulators in the highly rated groups than in the lower rated groups. Overall, the evidence suggests that highly rated organizations overstate their program expenses and understate their fundraising expenses. 
TABLE 3

Test of Differences between the Star Ratings

\begin{tabular}{|c|c|c|c|c|c|c|c|c|c|c|}
\hline & $4-3$ & $4-2$ & $4-1$ & $4-0$ & $3-2$ & $3-1$ & $3-0$ & $2-1$ & $2-0$ & $\frac{1-0}{-1.326}$ \\
\hline FResid & $\begin{array}{l}264 \\
\star \star \star \star\end{array}$ & $\begin{array}{l}-397 \\
\star \star \star \star\end{array}$ & $\begin{array}{l}-604 \\
\star * \star *\end{array}$ & $\begin{array}{l}-1,930 \\
\star \star \star \star\end{array}$ & $\begin{array}{l}-133 \\
\star \star \star \star\end{array}$ & $\begin{array}{l}340 \\
* \star \star \star\end{array}$ & $\begin{array}{l}-1,666 \\
\star \star \star \star\end{array}$ & $\begin{array}{l}-207 \\
\star \star \star \star\end{array}$ & $\begin{array}{l}-1,533 \\
\star \star \star \star\end{array}$ & $\begin{array}{l}-1,326 \\
\star \star \star \star\end{array}$ \\
\hline AResid & 58 & -65 & $\begin{array}{l}-189 \\
* \star\end{array}$ & $\begin{array}{l}144 \\
* \star *\end{array}$ & 7 & -131 & $\begin{array}{l}202 \\
* * *\end{array}$ & -124 & $\begin{array}{l}209 \\
* * *\end{array}$ & $\begin{array}{l}333 \\
\star * \star *\end{array}$ \\
\hline PResid & $\begin{array}{l}02 \\
* * * *\end{array}$ & $\begin{array}{l}03 \\
* * *\end{array}$ & $\int_{* \star \star}^{05}$ & $\begin{array}{l}10 \\
\star \star \star \star\end{array}$ & $\underbrace{01}_{\star \star \star \star \star}$ & $\begin{array}{l}.03 \\
\star \star \star \star\end{array}$ & $\begin{array}{l}08 \\
\star \star \star \star\end{array}$ & $\begin{array}{l}-02 \\
\star \star \star \star\end{array}$ & $\begin{array}{l}.07 \\
\star \star \star \star\end{array}$ & $\begin{array}{l}.05 \\
* * *\end{array}$ \\
\hline ManPR & O9 & $\begin{array}{l}13 \\
\star \star \star \star\end{array}$ & 28 & $\begin{array}{l}38 \\
\star \star \star \star *\end{array}$ & .04 & $\begin{array}{l}19 \\
* \star \star\end{array}$ & $\begin{array}{l}29 \\
* \star \star \star\end{array}$ & $\begin{array}{l}15 \\
\star \star \star \star\end{array}$ & $\begin{array}{l}25 \\
* \star \star\end{array}$ & $\begin{array}{l}10 \\
*\end{array}$ \\
\hline
\end{tabular}

Note: The table represents the average difference in the variables for different star comparisons. $* \star *, * \star, *$ statistically significant at the $1 \%, 5 \%$, and $10 \%$ respectively. The $z$-statistic is the reported test statistic for test of differences. FResid $=$ The residual (in $\$ O O O$ ) from the fundraising expense expectation model; AResid $=$ The residual (in \$OOO) from the administrative expense expectation model; PResid $=$ The standardized residual from the program expense expectation model; ManPR $=1$ if the standardized PResid is positive and statistically greater than zero at the $99 \%$ confidence level.

While the preceding analyses support the notion that higher rated nonprofits overstate program expenses and understate fundraising expenses, it is not clear that these results hold after controlling for factors known to be associated with misreporting. Table 4 provides descriptive statistics by rating of measures found by Yetman and Yetman (2012) to be associated with misreporting of overhead expenses. These control variables are available for 1,151 observations. Four-star organizations tend to be younger than lower rated organizations, more likely to receive an A-133 audit, have more assets, and more likely to have outstanding tax exempt bonds.

Table 5 presents the multivariate results with the residuals from the three expectation models representing the dependent variable respectively. Along with control variables, an independent variable is included for the overall rating of an organization. In addition, separate models are run with the independent variable of ratings replaced by a dichotomous variable for whether an organization is four-star rated or 
TABLE 4

Descriptive Statistics of Control Variables by Rating

\begin{tabular}{|c|c|c|c|c|c|}
\hline \multicolumn{6}{|l|}{ Overall Rating $=0$} \\
\hline Variable & Obs & Mean & Std. Dev. & Min & Max \\
\hline Donor Restriction & 15 & 0.04 & 0.16 & -0.11 & 0.61 \\
\hline Outside Accountant & 15 & 0.47 & 0.52 & 0.00 & 1.00 \\
\hline Age & 15 & 16.93 & 11.62 & 5.00 & 47.00 \\
\hline Audit A-133 & 15 & 0.00 & 0.00 & 0.00 & 0.00 \\
\hline Current Ratio & 15 & 22.76 & 49.03 & 0.00 & 186.38 \\
\hline Total Assets & 15 & 1,466 & 2.061 & 6 & 7,711 \\
\hline Municipal Bonds & 15 & 0.00 & 0.00 & 0.00 & $0.0 \overline{0}$ \\
\hline Voting Directors & 15 & 6.67 & 4.45 & 0.00 & 14.00 \\
\hline \multicolumn{6}{|l|}{ Overall Rating $=1$} \\
\hline Variable & Obs & Mean & Std. Dev. & Min & Max \\
\hline Donor Restriction & 102 & 0.25 & 0.31 & 0.00 & 1.24 \\
\hline Outside Accountant & 102 & 0.58 & 0.50 & 0.00 & 1.00 \\
\hline Age & 102 & 37.16 & 17.63 & 6.00 & 73.00 \\
\hline Audit A-133 & 102 & 0.16 & 0.37 & 0.00 & 1.00 \\
\hline Current Ratio & 102 & 27.10 & 126.81 & 0.00 & $1,236.34$ \\
\hline Total Assets & 102 & 10,600 & 22,600 & 64 & 146,000 \\
\hline Municipal Bonds & 102 & 0.03 & 0.17 & 0.00 & 1.00 \\
\hline Voting Directors & 102 & 16.32 & $1 \overline{3.12}$ & 0.00 & 108.00 \\
\hline \multicolumn{6}{|l|}{ Overall Rating $=2$} \\
\hline Variable & Obs & Mean & Std. Dev. & Min & Max \\
\hline Restri & 262 & 0.26 & 0.27 & 0.00 & 1.87 \\
\hline Outside Accol & 262 & 0.55 & 0.50 & 0.00 & 1.00 \\
\hline Age & 262 & 37.57 & 40.13 & 4.00 & 611.00 \\
\hline-133 & 262 & 0.33 & 0.47 & 0.00 & 1.00 \\
\hline Current Ratio & 262 & 68.95 & 847.07 & 0.00 & $13,710.44$ \\
\hline Total Assets & 262 & 24,000 & 91,200 & 355 & 870,000 \\
\hline Municipal Bonds & 262 & 0.04 & 0.19 & 0.00 & 1.00 \\
\hline Voting Directors & 262 & 20.51 & 16.84 & 0.00 & 132.00 \\
\hline \multicolumn{6}{|l|}{ Overall Rating $=\mathbf{3}$} \\
\hline Variable & Obs & Mean & Std. Dev. & Min & Max \\
\hline Donor Restriction & 420 & 0.31 & 1.28 & -0.28 & 26.06 \\
\hline Outside Accountant & 420 & 0.60 & 0.49 & 0.00 & 1.00 \\
\hline Age & 420 & 34.05 & 18.82 & 5.00 & $84 . \overline{00}$ \\
\hline-133 & 420 & 0.37 & 0.48 & 0.00 & 1.00 \\
\hline rent Ratio & 420 & 9.36 & 67.48 & $-1,231.21$ & 448.63 \\
\hline Total Assets & 420 & 23,400 & 50,300 & 191 & 352,000 \\
\hline ipal Bonds & 420 & 0.06 & 0.25 & 0.00 & 1.00 \\
\hline Voting Directors & 420 & 24.78 & 31.02 & 0.00 & $474.0 \overline{0}$ \\
\hline
\end{tabular}


TABLE 4 (Continued)

\begin{tabular}{|c|c|c|c|c|c|}
\hline \multicolumn{6}{|l|}{ Overall Rating $=\mathbf{3}$} \\
\hline Variable & $\underline{\mathrm{Obs}}$ & Mean & Std. Dev. & Min & Max \\
\hline Donor Restriction & $\overline{420}$ & 0.31 & 1.28 & $-0 . \overline{28}$ & $\overline{26.06}$ \\
\hline Outside Accountant & 420 & 0.60 & 0.49 & 0.00 & 1.00 \\
\hline Age & 420 & 34.05 & 18.82 & 5.00 & 84.00 \\
\hline Audit A-133 & 420 & 0.37 & 0.48 & 0.00 & 1.00 \\
\hline Current Ratio & 420 & 9.36 & 67.48 & $-1,231.21$ & 448.63 \\
\hline Total Assets & 420 & 23,400 & 50,300 & 191 & 352,000 \\
\hline Municipal Bor & 420 & 0.06 & 0.25 & 0.00 & 1.00 \\
\hline Voting Directors & 420 & 24.78 & 31.02 & 0.00 & 474.00 \\
\hline \multicolumn{6}{|l|}{ Overall Rating $=4$} \\
\hline Variable & Obs & Mean & Std. Dev. & Min & Max \\
\hline Don & 352 & 0.26 & 0.26 & -0.09 & 1.14 \\
\hline Outside Accountant & 352 & 0.58 & 0.49 & 0.00 & 1.00 \\
\hline Age & 352 & 31.22 & 18.86 & 4.00 & 87.00 \\
\hline Audit A-133 & 352 & 0.47 & 0.50 & 0.00 & 1.00 \\
\hline Current Ratio & 352 & 21.80 & 76.40 & 0.06 & $1,300.26$ \\
\hline Total Assets & 352 & 35,300 & 247,000 & 96 & $4,510,000$ \\
\hline Municipal Bonds & 352 & 0.07 & 0.26 & 0.00 & 1.00 \\
\hline Voting Directors & 352 & 23.62 & 18.29 & 0.00 & 59.00 \\
\hline
\end{tabular}

Note: The total number of observations drops from 2,632 to 1,151 due to missing observations for the control variables. The variables are defined as follows: Donor Restriction = Restricted Net Assets / Total Net Assets; Outside Accountant $=1$ if reported accounting fees is greater than zero; Age $=$ the age of the organization measured by subtracting the current year from the ruling year; Audit $\mathrm{A}-133=1$ if the organization reports greater than $\$ 500,000$ in government grants; Current Ratio = (cash + savings + securities investments) / (total liabilities - mortgage payable tax exempt bonds); Total Assets = total end of year assets (in \$0OO); Municipal Bonds $=1$ if the organization reports tax exempt bonds; Voting Directors $=$ the number of voting board members.

not. The regression results are consistent with the previously discussed univariate results. Specifically, the coefficients on both the overall rating and the four-star rating variables are positive and statistically significant for the residual program ratio model, negative for the residual fundraising expense model, and not significant for the residual administrative expense model. These results suggest that after controlling for other known factors associated with misreporting 
overhead costs, higher rated organizations are more apt to overstate their program expenses and understate their fundraising expenses.

TABLE 5

Regression Results for Program Ratio, Fundraising Expense, and Administrative Expense Residuals

\begin{tabular}{|c|c|c|c|c|c|c|}
\hline & \begin{tabular}{|l} 
Residual \\
Program \\
Ratio
\end{tabular} & $\begin{array}{l}\text { Residual } \\
\text { Program } \\
\text { Ratio }\end{array}$ & $\begin{array}{l}\text { Residual } \\
\text { Fundraising } \\
\text { Expense }\end{array}$ & $\begin{array}{l}\text { Residual } \\
\text { Fundraising } \\
\text { Expense }\end{array}$ & $\begin{array}{l}\text { Residual } \\
\text { Admin } \\
\text { Expense }\end{array}$ & $\begin{array}{l}\text { Residual } \\
\text { Admin } \\
\text { Expense }\end{array}$ \\
\hline $\begin{array}{l}\text { Overall } \\
\text { Rating }\end{array}$ & $\begin{array}{l}.02^{\star \star *} \\
(5.34)\end{array}$ & & $\begin{array}{l}-255.98 * \star \star \\
(-4.10)\end{array}$ & & $\begin{array}{l}-54.15 \\
(-0.90)\end{array}$ & \\
\hline Four Star & & $\begin{array}{l}.02 \star \star \star \\
(4.92)\end{array}$ & & $\begin{array}{l}-403.72 * \star \star \\
(-2.84)\end{array}$ & & $\begin{array}{l}-85.81 \\
(-1.07)\end{array}$ \\
\hline $\begin{array}{l}\text { Donor } \\
\text { Restriction }\end{array}$ & $\begin{array}{l}.00 \\
(-1.43)\end{array}$ & $\begin{array}{l}.00 \\
(-1.26)\end{array}$ & $\begin{array}{l}-16.97 \\
(-0.73)\end{array}$ & $\begin{array}{l}-23.31 \\
(-0.97)\end{array}$ & $\begin{array}{l}43.64^{\star \star} \\
(2.28)\end{array}$ & $\begin{array}{l}42.29^{\star \star} \\
(2.15)\end{array}$ \\
\hline $\begin{array}{l}\text { Outside } \\
\text { Accountant }\end{array}$ & $\begin{array}{l}-.01 \\
(-1.17)\end{array}$ & $\begin{array}{l}-.01 \\
(-0.97)\end{array}$ & $\begin{array}{l}127.72 \\
(1.17)\end{array}$ & $\begin{array}{l}111.93 \\
(1.03)\end{array}$ & $\begin{array}{l}144.31 \\
(1.47)\end{array}$ & $\begin{array}{l}140.97 \\
(1.47)\end{array}$ \\
\hline Age & $\begin{array}{l}.00 \\
(-0.9)\end{array}$ & $\begin{array}{l}.00 \\
(-1.07)\end{array}$ & $\begin{array}{l}2.12 \\
(1.14)\end{array}$ & $\begin{array}{l}2.38 \\
(1.31)\end{array}$ & $\begin{array}{l}2.88 \\
(1.62)\end{array}$ & $\begin{array}{l}2.93 \\
(1.58)\end{array}$ \\
\hline Audit A-133 & $\begin{array}{l}-.02 \star \star \star \\
(-3.49)\end{array}$ & $\begin{array}{l}-.01{ }^{\star \star \star} \\
(-2.81)\end{array}$ & $\begin{array}{l}-380.10 * \star \star \\
(-2.88)\end{array}$ & $\begin{array}{l}-415.7 \star \star \star \\
(-3.08)\end{array}$ & $\begin{array}{l}-5.00 \\
(-0.06)\end{array}$ & $\begin{array}{l}-12.48 \\
(-0.16)\end{array}$ \\
\hline $\begin{array}{l}\text { Current } \\
\text { Ratio }\end{array}$ & $\begin{array}{l}.00 \\
(-0.7)\end{array}$ & $\begin{array}{l}.00 \\
(-1.05)\end{array}$ & $\begin{array}{l}-.05 * \star \star \\
(-4.38)\end{array}$ & $\begin{array}{l}-.04 \star \star \star \\
(-3.36)\end{array}$ & $\begin{array}{l}-.03 \\
(-1.4)\end{array}$ & $\begin{array}{l}-02 \\
(-1.39)\end{array}$ \\
\hline Total Assets & $\begin{array}{l}.00 \\
(-1.16)\end{array}$ & $\begin{array}{l}.00 \\
(-1.22)\end{array}$ & $\begin{array}{l}.00 \\
(-1.56)\end{array}$ & $\begin{array}{l}.00 \\
(-1.57)\end{array}$ & $\begin{array}{l}00 \star \star \star \\
(-2.81)\end{array}$ & $\begin{array}{l}00 * \star \star \\
(-2.82)\end{array}$ \\
\hline $\begin{array}{l}\text { Municipal } \\
\text { Bonds }\end{array}$ & $\begin{array}{l}-.02^{\star \star} \\
(-2.16)\end{array}$ & $\begin{array}{l}-.01^{\star} \\
(-1.92)\end{array}$ & $\begin{array}{l}-516.71 \star \\
(-1.68)\end{array}$ & $\begin{array}{l}-543.47^{\star} \\
(-1.75)\end{array}$ & $\begin{array}{l}944.38^{\star \star} \\
(2.28)\end{array}$ & $\begin{array}{l}938.75 * * \\
(2.26)\end{array}$ \\
\hline $\begin{array}{l}\text { Voting } \\
\text { Directors }\end{array}$ & $\begin{array}{l}.00^{\star \star} \\
(2.38)\end{array}$ & $\begin{array}{l}.00^{\star \star \star \hbar} \\
(2.82)\end{array}$ & $\begin{array}{l}-.64 \\
(-0.2)\end{array}$ & $\begin{array}{l}-1.97 \\
(-0.61)\end{array}$ & $\begin{array}{l}-2.97 \\
(-0.8)\end{array}$ & $\begin{array}{l}-3.25 \\
(-0.88)\end{array}$ \\
\hline $\begin{array}{l}\text { Voting } \\
\text { Directors } 2\end{array}$ & $\begin{array}{l}.00^{\star \star \star} \\
(-3.37)\end{array}$ & $\begin{array}{l}.00^{* \star \star} \\
(-3.65)\end{array}$ & $\begin{array}{l}.00 \\
(0.64)\end{array}$ & $\begin{array}{l}.01 \\
(0.91)\end{array}$ & $\begin{array}{l}01 \\
(0.96)\end{array}$ & $\begin{array}{l}.01 \\
(1.01)\end{array}$ \\
\hline $\begin{array}{l}\text { State } \\
\text { Control }\end{array}$ & Yes & Yes & Yes & Yes & Yes & Yes \\
\hline $\bar{N}$ & 1,151 & 1,151 & 1,151 & 1,151 & 1,151 & 1,151 \\
\hline R-Square & $9 \%$ & $7 \%$ & $16 \%$ & $15 \%$ & $10 \%$ & $10 \%$ \\
\hline
\end{tabular}

Note: Coefficient estimates and t-statistics (in parentheses) are presented. Control variables are previously defined in Table 4 . All models include controls for state of location and standard errors clustered by EIN. Overall Rating $=$ the star rating received by an organization (i.e. 0-4); Four Star $=1$ if an organization is rated four stars. Significance tests are two-tailed. $*, \star \star, * \star \star$ represent significance levels of 10 percent, 5 percent and 1 percent respectively. 
To understand how highly rated nonprofits misstate their expenses, we further examine three obvious misreporting practices. First, consistent with prior literature that finds organizations understate fundraising expenses, we measure whether organizations receive direct public support but report zero fundraising expenses (Krishnan et al., 2006; Yetman \& Yetman, 2012). Our second measure tests whether organizations report zero officer compensation. Nonprofits have been scrutinized in recent years for paying their officers excessive compensation. Failure to report officer compensation on Form 990 is indicative of an organization not being transparent in compensation reporting and has been utilized in prior literature as a measure of reporting quality (Neely, 2011). Finally, we measure whether organizations report joint costs. Prior literature finds that organizations utilize joint cost allocations to smooth their program expense ratio (Jones \& Roberts, 2006).

As Table 6 shows, the program expense ratio increases with the ratings. This is not surprising because one of the variables utilized in Charity Navigator's rating scheme is the program expense ratio. However, the descriptive statistics show that four-star organizations, the highest rated group, report fewer incidences of zero executive compensation, joint cost allocations, or zero fundraising. The threestar group also reports fewer incidences of joint cost allocations. Its reporting of zero compensation and zero fundraising are comparable to those of the lower rated groups. The tests of differences in Table 7 suggest that statistically the likelihood of reporting zero compensation or zero fundraising is not different between highly rated groups and lower rated groups. The reporting of joint costs is less likely in the highly rated groups.

While the three measures of obvious misreporting do not support the finding that highly rated nonprofits are more likely to misstate their financials, a closer look at their expense allocations suggests how they are able to accomplish a higher program expense ratio. We checked the labor related expenses of the sample. On average, nonprofits spend $38 \%$ of total expenses on officer compensation and other employee wages and benefits. Also reported in Table 6 , the percentages of wages, benefits, and joint costs allocated to program expense (compared to fundraising or administrative expense) are all higher for highly rated nonprofits. Given the discretion involved in 
TABLE 6

Descriptive Statistics for Variables of Interest

\begin{tabular}{|l|l|c|c|c|c|c|}
\hline Variable & & $4-S t a r$ & 3-Star & 2-Star & 1-Star & O-Star \\
\hline ProgExpRatio & Mean & 0.87 & 0.83 & 0.79 & 0.68 & 0.22 \\
\cline { 2 - 7 } & Median & 0.87 & 0.83 & 0.80 & 0.70 & 0.15 \\
\hline ZeroComp & Mean & 0.09 & 0.12 & 0.12 & 0.11 & 0.15 \\
\hline JointCost & Mean & 0.09 & 0.10 & 0.14 & 0.25 & 0.35 \\
\hline ZeroFundR & Mean & 0.00 & 0.01 & 0.01 & 0.01 & 0.02 \\
\hline CompRate & Mean & 0.53 & 0.54 & 0.53 & 0.55 & 0.51 \\
\cline { 2 - 7 } & Median & 0.64 & 0.64 & 0.56 & 0.60 & 0.51 \\
\hline \multirow{2}{*}{ WageRate } & Mean & 0.81 & 0.80 & 0.77 & 0.73 & 0.42 \\
\cline { 2 - 7 } & Median & 0.84 & 0.83 & 0.79 & 0.76 & 0.33 \\
\hline \multirow{2}{*}{ BenefitsRate } & Mean & 0.80 & 0.79 & 0.75 & 0.70 & 0.42 \\
\cline { 2 - 7 } & Median & 0.82 & 0.81 & 0.79 & 0.74 & 0.38 \\
\hline \multirow{2}{*}{ JointRate } & Mean & 0.73 & 0.65 & 0.63 & 0.51 & 0.22 \\
\cline { 2 - 7 } & Median & 0.82 & 0.72 & 0.69 & 0.50 & 0.17 \\
\hline Sample Size & & 748 & 945 & 632 & 252 & 55 \\
\hline
\end{tabular}

Note: This table represents descriptive statistics for the sample based on their Charity Navigator Rating.

ProgExpRatio $=$ Program Expenses $/$ Total Expenses; ZeroComp $=1$ if officer compensation is zero or missing; JointCost $=1$ if the organization reports having joint costs; ZeroFundR $=1$ if the organization reports direct public support and zero fundraising expenses; CompRate $=$ The percentage of officer compensation allocated to programs; WageRate = The percentage employee wages (other than officers) allocated to programs; BenefitsRate $=$ the percentage of employee benefits allocated to programs; JointRate $=$ the percentage of total joint costs allocated to programs.

making these expense allocations, it is probable that generous expense allocations to programs are responsible for some of the reported performance differential between highly rated nonprofits and lower rated nonprofits. Statistical tests in Table 7 confirm that the expense allocation to programs is more generous in highly rated nonprofits compared to their lower rated peers. Specifically, four- and three-star organizations allocate a greater percentage of wages, benefits, and joint costs to programs relative to zero- to two-star organizations. 
TABLE 7

Test of Differences between the Star Ratings

\begin{tabular}{|c|c|c|c|c|c|c|c|c|c|c|}
\hline Variable & $4-3$ & $4-2$ & 4-1 & 4-O & $3-2$ & 3-1 & 3-O & $2-1$ & $2-0$ & 1-0 \\
\hline $\begin{array}{l}\text { ProgExp } \\
\text { Ratio }\end{array}$ & $\begin{array}{l}.04 \\
* * *\end{array}$ & .08 & $\begin{array}{l}.19 \\
\star \star \star\end{array}$ & $\begin{array}{l}.65 \\
\star \star \star *\end{array}$ & $\begin{array}{l}.04 \\
\star \star \star\end{array}$ & $\begin{array}{l}.15 \\
\star \star \star\end{array}$ & $\begin{array}{l}.61 \\
\star \star *\end{array}$ & $\begin{array}{l}.11 \\
\star \star \star\end{array}$ & $\begin{array}{l}.57 \\
\star \star \star\end{array}$ & $\begin{array}{l}.46 \\
\star \star \star\end{array}$ \\
\hline $\begin{array}{l}\text { Zero } \\
\text { Comp }\end{array}$ & -.03 & -.03 & -.02 & -.06 & .00 & .01 & -.03 & .01 & -.03 & -.04 \\
\hline $\begin{array}{l}\text { Joint } \\
\text { Cost }\end{array}$ & -.01 & $\begin{array}{c}-.05 \\
\star \star\end{array}$ & $\begin{array}{l}-.16 \\
* \star \star\end{array}$ & $\begin{array}{l}-.26 \\
\star \star \star\end{array}$ & $\begin{array}{c}-.04 \\
* \star \\
\end{array}$ & $\begin{array}{l}-.15 \\
\star \star \star\end{array}$ & $\begin{array}{l}-.25 \\
\star \star \star\end{array}$ & $\begin{array}{l}-.09 \\
\star \star \star\end{array}$ & $\begin{array}{l}.21 \\
\star \star \star\end{array}$ & -.10 \\
\hline $\begin{array}{l}\text { Zero } \\
\text { FundR }\end{array}$ & -.01 & $\begin{array}{c}-.01 \\
\star\end{array}$ & -.01 & -.02 & .00 & .00 & -.01 & .00 & -.01 & -.01 \\
\hline $\begin{array}{l}\text { Comp } \\
\text { Rate }\end{array}$ & -.01 & .00 & -.02 & .02 & .01 & -.01 & .03 & -.02 & .02 & .04 \\
\hline $\begin{array}{l}\text { Wage } \\
\text { Rate }\end{array}$ & $\begin{array}{c}.01 \\
\star\end{array}$ & $\begin{array}{l}.04 \\
\star \star \star\end{array}$ & $\begin{array}{l}.08 \\
\star \star \star \star\end{array}$ & $\begin{array}{l}.39 \\
\star \star \star\end{array}$ & $\begin{array}{l}.03 \\
\star \star \star\end{array}$ & $\begin{array}{l}.07 \\
\star \star \star\end{array}$ & $\begin{array}{r}.38 \\
\star \star \star\end{array}$ & $\begin{array}{l}.04 \\
\star \star \star *\end{array}$ & $\begin{array}{l}.35 \\
\star \star \star\end{array}$ & $\begin{array}{l}.31 \\
\star \star \star *\end{array}$ \\
\hline $\begin{array}{l}\text { Benefits } \\
\text { Rate }\end{array}$ & $\begin{array}{c}.01 \\
\star\end{array}$ & $\begin{array}{l}.05 \\
\star * *\end{array}$ & $\begin{array}{l}.10 \\
* \star \star\end{array}$ & $\begin{array}{r}.38 \\
* * *\end{array}$ & $\begin{array}{l}.04 \\
* * \star\end{array}$ & $\begin{array}{l}.09 \\
\star \star \star\end{array}$ & $\begin{array}{l}.37 \\
\star \star \star\end{array}$ & $\begin{array}{l}.05 \\
\star \star \star\end{array}$ & $\begin{array}{l}.33 \\
\star \star \star\end{array}$ & $\begin{array}{l}.28 \\
\star \star \star\end{array}$ \\
\hline $\begin{array}{l}\text { Joint } \\
\text { Rate }\end{array}$ & $\begin{array}{l}.08 \\
\star \star\end{array}$ & $\begin{array}{l}.10 \\
\star \star \star\end{array}$ & $\begin{array}{l}.22 \\
\star \star \star\end{array}$ & $\begin{array}{l}.51 \\
\star * *\end{array}$ & .02 & $\frac{114}{\star \star \star}$ & $\begin{array}{l}.43 \\
\star \star \star\end{array}$ & $\begin{array}{l}.12 \\
\star \star \star\end{array}$ & $\begin{array}{l}.41 \\
\star \star \star\end{array}$ & $\begin{array}{l}.29 \\
\star \star \star\end{array}$ \\
\hline
\end{tabular}

Note: This table represents the average difference in the variables of interest for different star comparisons. $* \star \star, * \star$, and $*$ statistically significant at the $1 \%, 5 \%$, and $10 \%$ respectively. The $z$-statistic is the reported test statistic for test of differences. ProgExpRatio = Program Expenses / Total Expenses; ZeroComp $=1$ if officer compensation is zero or missing; JointCost $=1$ if the organization reports having joint costs; ZeroFundR $=1$ if the organization reports direct public support and zero fundraising expenses; CompRate = The percentage of officer compensation allocated to programs; WageRate $=$ The percentage employee wages (other than officers) allocated to programs; BenefitsRate $=$ the percentage of employee benefits allocated to programs; JointRate $=$ the percentage of total joint costs allocated to programs.

\section{CONCLUSION}

Prior research has shown that many donors utilize ratings for decisions (Tinkelman, 1998; Sloan, 2009; Gordon et al., 2009). What is not clear is whether charitable organizations manage their numbers to achieve a higher rating. The findings from this study indicate that highly rated organizations likely overstate their performance compared to their lower rated peers. Highly rated organizations appear to be exercising accounting discretion to 
increase their program expenses and decrease their fundraising expenses. Stakeholders relying on the rating systems should consider this possibility and consider additional data (such as nonfinancial information) before making definitive conclusions about the performance of a highly rated nonprofit organization. Prior research shows that after the passage of the AICPA's SOP 98-2, some nonprofits stopped allocating joint costs and those that continued to report joint costs allocated less to programs (Roberts, 2005). Because reported high performance can be achieved by using discretion in allocating expenses to the program expense category, it would be beneficial if accounting regulators and/or the IRS provided more guidance on the allocation of expenses shared by program, fundraising, and administrative activities. Given nonprofit boards' financial oversight duty, the IRS suggests that boards review Form 990s before they are filed (Kehrer \& Matthews, 2009). Consistent with the IRS' point of view, our findings suggest boards exercise due diligence in assessing the reasonableness of the expense allocation and whether the allocations are consistent over time.

\section{ACKNOWLEDGMENTS}

We thank Guidestar for providing some of the data used in this study.

\section{NOTES}

1. This information is obtained from the Internal Revenue Service (IRS) website. See the IRS Statistics of Income (SOI) Bulletin: Fall 2002 (http://www.irs.gov/pub/irs-soi/99eochar.pdf) and the soi Bulletin: Fall 2011 (www.irs.gov/pub/irs-soi/11eofallbulteorg.pdf) for more details.

2. On September 20,2011 , Charity Navigator launched a new rating system, which adds accountability and transparency indicators to the original seven financial performance measures.

3. Yetman and Yetman (2012) include industry indicator variables in their fundraising expense and administrative expense models. The model by Trussel (2003) also has charity type indicators. Even though our observations are all human service organizations, Charity Navigator further classifies them into six groups based on 1) the activity code each organization selects in 
its fillings with the IRS, 2) the description of the organization's programs and services, and 3 ) how the organization functions financially (www.charitynavigator.org/index.cfm?bay $=$. content. view\&cpid= 34). The group classification reflects the rating agency's industry knowledge.

\section{REFERENCES}

Baber, W., Roberts, A., \& Visvanathan, G. (2001). "Charitable Organizations' Strategies and Program Spending Ratios." Accounting Horizons, 15 (4): 329-343.

Bhattacharya R., \& Tinkelman, D. (2009). "How Tough are Better Business Bureau/Wise Giving Alliance Financial Standards?" Nonprofit and Voluntary Sector Quarterly, 38 (3): 467-489.

Callen, J.L. (1994). "Money Donations, Volunteering and Organizational Efficiency." Journal of Productivity Analysis, 67 (3): 215-228.

Fama, E., \& Jensen, M. (1983). "Agency Problems and Residual Claims." The Journal of Law and Economics, 26 (2): 327-350.

Government Accountability Office (GAO). (2002). "Tax Exempt Organizations: Improvements Possible in Public, IRS, and State Oversight of Charities." [On-line]. Available at http://www.gao.gov/products/GAO-02-526 [Retrieved November 29, 2011]

Gordon, T.P., Greenlee, J., \& Nitterhouse, D. (1999). “Tax-Exempt Organization Financial Data: Availability and Limitations." Accounting Horizons, 13: 113-128.

Gordon, T.P., Knock, C.L., \& Neely, D.G. (2009). “The Role of Rating Agencies in the Market for Charitable Contributions: An Empirical Test." Journal of Accounting Public Policy, 28: 469-484.

Gordon, T.P., \& Khumawala, S.B. (1999). "The Demand for Not-forProfit Financial Statements: A Model for Individual Giving." Journal of Accounting Literature, 18: 31-56.

Greenlee, J.S., \& Brown, K.L. (1999). "The Impact of Accounting Information on Contributions to Charitable Organizations." Research in Accounting Regulation, 13: 111-125. 
Hansmann, H. B. (1980). "The Role of Nonprofit Enterprise." Yale Law Journal, 89 (5): 835-901.

Jones, C., \& Roberts, A.A. (2006). "Management of Financial Information in Charitable Organizations: The Case of Joint-Cost Allocations." Accounting Review, 81 (1): 159-178.

Kehrer, K., \& J. M. Matthews. (2009). Having good policies is good policy. Taxation of Exempts 20 (5): 19-27.

Keating, E.K., Parsons, L.M., \& Roberts, A.A. (2008). "Misreporting Fundraising: How do Nonprofit Organizations Account for Telemarketing Campaigns?" The Accounting Review, 83 (2): 417446.

Krishnan, R., Yetman, M.H., \& Yetman, R.J. (2006). “Expense Misreporting in Nonprofit Organizations." The Accounting Review, 81 (2): 399-420.

Neely, D.G. (2011). "The Impact of Regulation on the U.S. Nonprofit Sector: Initial Evidence from the Nonprofit Integrity Act of 2004." Accounting Horizons, 25 (1): 1-24.

Parsons, L.M. (2003). "Is Accounting Information from Nonprofit Organizations Useful to Donors? A Review of charitable Giving and Value-Relevance." Journal of Accounting Literature, 22: 104-129.

Posnett, J., \& Sandler, T. (1989). “Demand for Charity Donations in Private Non-Profit Markets: The Case of the UK." Journal of Public Economics, 40 (2): $187-200$.

Roberts, A.A. (2005). "The Implications of Joint Cost Standards for Charity Reporting." Accounting Horizons, 19 (1): 11-23.

Rose-Ackerman, S. (1987). "Ideals versus Dollars: Donors, Charity Managers, and Government Grants." Journal of Political Economy, 95 (4): 810-823.

Sloan, M.F. (2009). "The Effects of Nonprofit Accountability Ratings on Donor Behavior." Nonprofit and Voluntary Sector Quarterly, 38 (2): 220-236.

Steinberg, R. (1986). “The Revealed Objective Functions of Nonprofit Firms." The RAND Journal of Economics, 17 (4): 508-526.

Tinkelman, D. (1998). "Difference in Sensitivity of Financial Statement Users to Joint Cost Allocations: The Case of Nonprofit 
Organizations." Journal of Accounting, Auditing \& Finance, 13 (4): 377-394.

Tinkelman, D. (1999). "Factors Affecting the Relation between Donations to Not-for-Profit Organizations and an Efficiency Ratio." Research in Government and Nonprofit Accounting, 10: 135-161.

Tinkelman D. (2009). "Unintended Consequences of Expense Ratio Guidelines;: The Avon Breast Cancer Walks." Journal of Accounting and Public Policy, 28: 485-494.

Tinkelman D. \& Mankaney, K. (2007). "When is Administrative Efficiency Associated with Charitable Donations?" Nonprofit and Voluntary Sector Quarterly, 36 (1): 41-64.

Trussel, J.M. (2003). “Assessing Potential Accounting Manipulation: The Financial Characteristics of Charitable Organizations with Higher than Expected Program-Spending Ratios." Nonprofit and Voluntary Sector Quarterly, 32 (4): 616-634.

Weisbrod, B.A. \& Dominguez, N.D. (1986). "Demand for collective Goods in Private Markets: Can Fundraising Expenditures Help Overcome Free-Rider Behavior?" Journal of Public Economics, 30 : 83-96.

Wing, K., Gordon, T., Hager, M., Pollak, T. \& Rooney, P. (2006). "Functional Expense Reporting for Nonprofits." The CPA Journal, 76 (8): 14-18.

Wong, C.M., Chua, V.C.H., \& Vasoo, S. (1998). "Contributions to Charitable Organizations in a Developing Country: The Case of Singapore." International Journal of Social Economics, 25 (1): 25-42.

Yetman, R.J. (2001). "Tax-Motivated Expense Allocations by Nonprofit Organizations." The Accounting Review, 76 (3): 297-311.

Yetman, M.H., \& Yetman, R.J. (2012). “The Effects of Governance on the Accuracy of Charitable Expenses Reported by Nonprofit Organizations." Contemporary Accounting Research, 29 (3): 738767. 